\title{
Agaricaceae Fr. (Agaricales, Basidiomycota) from areas of Atlantic Forest in Pernambuco, Brazil ${ }^{1}$
}

\author{
Felipe Wartchow ${ }^{2,4}$, Jair Putzke ${ }^{3}$ and Maria Auxiliadora de Queiroz Cavalcanti ${ }^{2}$
}

Received: July 20, 2006. Accepted: June 4, 2007

\begin{abstract}
RESUMO - (Agaricaceae Fr. (Agaricales, Basidiomycota) em áreas de Mata Atlântica do Estado de Pernambuco, Brasil). O levantamento de Agaricaceae em áreas de Mata Atlântica na região metropolitana de Recife, Pernambuco, Brasil, revelou a ocorrência de nove espécies: Agaricus aff. parasilvaticus Heinem., A. purpurellus (F.H. Møller) F.H. Møller, A. rufoaurantiacus Heinem., Leucoagaricus sulphurellus (Pegler) B.P. Akers, Leucocoprinus cretaceus (Bull.: Fr.) Locq., L. fragilissimus (Ravenel) Pat., Lepiota elaiophylla Vellinga \& Huijser, L. erythrosticta (Berk. \& Broome) Sacc. e Micropsalliota brunneosperma (Singer) Pegler. Chave para identificação dessas espécies, descrições, ilustrações e comentários são apresentadas. Micropsalliota brunneosperma constitui nova referência para o Brasil.
\end{abstract}

Palavras-chave: Agaricales, neotrópicos, Nordeste Brasileiro, taxonomia

ABSTRACT - (Agaricaceae Fr. (Agaricales, Basidiomycota) from areas of Atlantic forest in Pernambuco State, Brazil). The survey of Agaricaceae in areas of the Atlantic Forest in the metropolitan region of Recife, state of Pernambuco, Brazil, revealed the presence of nine species: Agaricus aff. parasilvaticus Heinem., A. purpurellus (F.H. Møller) F.H. Møller, A. rufoaurantiacus Heinem., Leucoagaricus sulphurellus (Pegler) B.P. Akers, Leucocoprinus cretaceus (Bull.: Fr.) Locq., L. fragilissimus (Ravenel) Pat., Lepiota elaiophylla Vellinga \& Huijser, L. erythrosticta (Berk. \& Broome) Sacc. and Micropsalliota brunneosperma (Singer) Pegler. A key for identification of these species, descriptions, drawings and remarks are provided. Micropsalliota brunneosperma is reported for the first time for Brazil.

Key words: Agaricales, Neotropics, Northeast Brazil, taxonomy

\section{Introduction}

Agaricaceae Fr. sensu Singer (1986) includes 25 genera, most of them distributed over several continents and organized in four tribes: Leucocoprinae Singer, Agariceae Pat., Lepiotae Fayod and Cystodermatae Singer. According to Kirk et al. (2001), this family comprises 51 genera and 918 species, including several genera with gasteroid and secotioid basidiomata. Although some authors have considered species with light and those with dark spores to lie in two distinct families (Smith 1973; Bon 1993), molecular studies confirm the monophyly of this group, except for Cystodermateae (Johnson \& Vilgalys 1998; Vellinga 2004a).

Some changes in this family occurred after Singer (1986): the revaluation of Rugosospora Heinem. (Guzmán et al. 1989; Franco-Molano 1995); the exclusion of the tribe Cystodermatae from Agaricaceae (Johnson \& Vilgalys 1998; Vellinga 2004a); the inclusion of Coprinus comatus (O.F. Müll.: Fr.) Pers., C. sterquilinus (Fr.: Fr.) Fr. and C. spadiceisporus Bogart in this family (Redhead et al. 2001); the synonymization of Macrolepiota Singer section Laevistipedes (Pázmány) Bon with Chlorophyllum Massee (Vellinga 2002, 2003a; Vellinga \& de Kok 2002; Vellinga et al. 2003); the synonymization of Volvolepiota Singer with Macrolepiota (Vellinga \& Yang 2003; Vellinga et al. 2003); the transfer of Melanophyllum Velen. to the same clade as Lepiota (Pers.) Gray (Vellinga 2003b); the inclusion of the gasteroid genera of Lycoperdales and Tulostomatales (Agerer 2002; Moncalvo et al. 2002; Vellinga 2004a); the transfer of Cystoagaricus Singer to Psathyrellaceae (Singer) Redhead, Moncalvo \& Vilgalys (Vellinga 2004a); and the confirmation of the

\footnotetext{
1 Parte da Dissertação de Mestrado do primeiro Autor

2 Universidade Federal de Pernambuco, Departamento de Micologia, Centro de Ciências Biológicas, Av. Prof. Nelson Chaves, s.n., 50670-901 Recife, PE, Brazil

3 Universidade de Santa Cruz do Sul, Departamento de Biologia, 96815-900 Santa Cruz do Sul, RS, Brazil

4 Corresponding author: fwartchow@yahoo.com.br
} 
monophyly of Leucoagaricus (Locq.) ex Singer, Leucocoprinus Pat. and Sericeomyces Heinem., which can be treated as a single genus (Vellinga 2004a).

The earliest records of Agaricaceae in Brazil were published by Montagne (1856), who described several species of Agaricus sensu lato, most of them now synonymized in other genera of Agaricales not currently included in Agaricaceae (Pegler 1990). During the twentieth century and in the present one, several works reported Agaricaceae from various Brazilian States: Theissen (1912), Singer (1953), Rick (1961), Raithelhuber (1987a; b; 1988), Franco-Molano (1995), Pereira (1998; 2000), Spielmann \& Putzke (1998), Sobestiansky (2005) and Albuquerque et al. (2006) from Rio Grande do Sul; Heim (1957) and Pereira (1998) from Santa Catarina; Jezek (1973) from Rio de Janeiro; Bononi et al. (1981a; b; 1984), Grandi et al. (1984), Pegler (1997), Capelari \& Gimenes (2004) and Capelari et al. (2006) from São Paulo; Capelari \& Maziero (1988) from Rondônia; Singer (1973; 1989) and Singer \& Aguiar (1986) from Amazonas and Pará; Muchovej et al. (1991) from Minas Gerais; Bononi (1992) from Acre; Heinemann \& de Meijer (1996) and de Meijer (2001; 2006) from Paraná; Heinemann $(1989 ; 1993)$ from Mato Grosso, Paraná, Rio de Janeiro and São Paulo. In Northeast Brazil, Kimbrough et al. (1994; 1995) reported Chlorophyllum molybdites (G. Mey.: Fr.) Massee, Lepiota eyrthrosticta (Berk. \& Broome) Sacc. and L. teipeitensis Murrrill, and Maia et al. (2002) referred Agaricus purpurellus (F.H. Møller) F.H. Møller, A. brunneostictus Heinem., Leucoagaricus meleagris (J. Sowerby: Fr.) Singer [as Leucocoprinus meleagris (J. Sowerby) Locq.] and
Micropsalliota roseovinacea Pegler (as "M. roseovinaceus"), all from Pernambuco.

This work presents species of Agaricus L.: Fr., Leucoagaricus, Leucocoprinus, Lepiota and Micropsalliota Höhn., collected in areas of Atlantic Forest of the metropolitan region of Recife, Pernambuco, Brazil.

\section{Material and methods}

Basidiomata were collected at the "Parque Estadual de Dois Irmãos" (7'55'43 S and $35^{\circ} 00^{\prime} 59^{\prime \prime}$ W), with 388 ha in the Municipality of Recife and at the "Reserva Ecológica da Mata do Sistema Gurjaú" $\left(8^{\circ} 14^{\prime} 21^{\prime \prime} \mathrm{S}\right.$ and $\left.35^{\circ} 03^{\prime} 00^{\prime \prime} \mathrm{W}\right)$, with 1077 ha in the Municipality of Cabo de Santo Agostinho, both in Pernambuco State, Brazil (Secretaria Estadual de Ciência, Tecnologia e Meio Ambiente 2001) on July and August 2003, February and May to August 2004.

Usual techniques for the study of agarics were used (Singer 1986), and the colours of the basidiomata were named using Maerz \& Paul (1950). The "Q" values represent the quotient of the length/width of the basidiospores, and for each specimen at least 20 were measured. For identification of species, Pegler (1972; 1977; 1983; 1986), Pegler \& Rayner (1969), Heinemann (1961; 1977; 1983; 1989; 1993), Candusso \& Lanzoni (1990) and Vellinga \& Huijser (1997) were used.

The specimens studied were deposited at the Herbarium URM ("Departamento de Micologia, Universidade Federal de Pernambuco") and Herbarium HCB ("Departamento de Biologia, Universidade de Santa Cruz do Sul”).

\section{Results and discussion}

Key to species of Agaricaceae known from areas of Atlantic Forest in Pernambuco State

1. Basidiospores pigmented

2. Basidiospores dark green; endosporium thickening at the apex; cheilocystidia elongate and capitate 9. Micropsalliota brunneosperma

2. Basidiospores brown; endosporium not thickening at the apex; cheilocystidia clavate to piriform 3

3. Universal veil well developed and persistent on the pileus and stipe; pileus with orangebrown squamules on its surface 3. Agaricus rufoaurantiacus

3. Universal veil not well developed on the pileus and stipe surfaces; pileus surface with purplish or light brown squamules

4. Pileus with numerous, light brown squamules; stipe base without any evidence of colour change to yellow on handling 1. Agaricus aff. parasilvaticus

4. Pileus with purplish brown squamules; stipe base changing to yellow on handling 


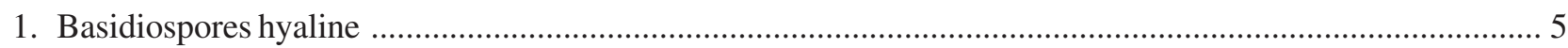

5. Basidiospores dextrinoid, with metachromatic endosporium ....................................................... 6

6. Pileus surface strongly sulcate; context very thin or translucent; lamellae colour not changing when bruising; pleurocystidia absent

7. Basidioma sub-deliquescent, very thin and fragile; pileus surface with yellow squamules; basidiospores ellipsoid 10-12.5×7.5-8.8 $\mu \mathrm{m}$, with the apical region short cylindrical

6. Leucocoprinus fragilissimus

7. Basidioma not deliquescent; pileal surface with white, floccose squamules, at least when young; basidiospores ellipsoid 6.2-10×5-7.5 $\mu \mathrm{m}$, without short cylindrical apical region .....

5. Leucocoprinus cretaceus

6. Pileus surface not, or only indistinctly sulcate; context thick; lamellae color changing to bluish green when bruising; pleurocystidia present 4. Leucoagaricus sulphurellus

5. Basidiospores dextrinoid, but endosporium not metachromatic 8

8. Basidiospores not truncate, ellipsoid to sub cylindrical; pileal surface sulphur-yellow with brown squamules.... 7. Lepiota elaiophylla

8. Basidiospores spurred with truncate base; pileal surface white with pinkish squamules 8. Lepiota erythrosticta

1. Agaricus aff. parasilvaticus Heinem., Bull. Jard. Bot. Brux. 32: 156. 1962.

Fig. 1-4

Pileus $29 \mathrm{~mm}$, convex and broadly umbonate; surface composed of numerous minute light brown (M\&P 13D10 “Tawny”) squamules on cream ground, darker and entire over disc; margin entire, not sulcate. Lamellae free, membranous, moderately crowded, dark grey. Stipe $41 \times 6 \mathrm{~mm}$, central, cylindrical, swollen at base (-8 mm), cream, with small squamules on the lower part; rhizomorphs present. Annulus persistent, superior, membranous, light brown. Context fleshy in disc, thin near margin. Basidiospores 3.8-5×2.5-3.5 $\mu \mathrm{m}$, in average $4.7 \times 2.8 \mu \mathrm{m}, \mathrm{Q}=(1.28-) 1.42-1.82(-2)$, ellipsoid in side view, smooth, with wall slightly thickened, brown. Basidia 13.8-17.5 $\times 5-6 \mu \mathrm{m}$, clavate, 4 sterigmata. Pleurocystidia absent. Cheilocystidia inconspicuous, 14-17 $\times 5-7.5 \mu \mathrm{m}$, broadly clavate or pyriform, thinwalled, hyaline. Pileipellis with repent hyphae 3-7.5 $\mu \mathrm{m}$ wide, thin-walled, with pale brown intracellular pigment. Hymenophoral trama regular. Clamp-connections absent.

Habitat: solitary on soil in tropical forest.

Material examined: BRAZIL. Pernambuco: Cabo de Santo Agostino, Complexo do Gurjaú (Mata do Coxiu), 26/VIII/2003, I.G. Baseia et al. s.n. (URM 78671).

Distribution: Venezuela (Heinemann 1962; Pegler 1983), Martinique, Trinidad (Pegler 1983). Brazil: Paraná (Heinemann 1993), São Paulo (Pegler 1997). This is the first record from Pernambuco.
Remarks: The small basidioma with small fibrillose squamules on the pileal surface and ellipsoid basidiospores place this species in section Sanguinolenti Jul. Schäff. \& F.H. Møller (Heinemann 1977). A related species is Agaricus earlei Murrill, from Cuba, with indistinctly apiculate and ellipsoid basidiospores $5 \times 3 \mu \mathrm{m}$ (Murrill 1918). Freeman (1979) revised the type of A. earlei and reported basidiospores 4.5-5.5×3-3.8 $\mu \mathrm{m}$. On the other hand, Pegler (1987) reported $A$. earlei as having larger basidiospores 6-7.5 $\times 3.4-4.2 \mu \mathrm{m}$ and did not observe any trace of yellow colour in the exsiccate nor in the original illustration and placed this species near to A. parasilvaticus. This discrepancy on the size of basidiospores of $A$. earlei makes an exact comparison between this species and $A$. parasilvaticus imprecise or impossible without reviewing the types. In the collection studied there was no colour change to yellow in the fresh basidioma, and the microscopic characters agree with the description of $A$. parasilvaticus given by Pegler (1983).

2. Agaricus purpurellus (F.H. Møller) F.H. Møller, Friesia 4: 204. 1952.

Psalliota purpurella F.H. Møller, Friesia 4: 193. 1952. Fig. 5-8

Pileus $18-45 \mathrm{~mm}$, plane to sometimes broadly umbonate, purplish brown (M\&P 8J7 "Liberia+") at the disc, disrupting into squamules on white or light grey ground. Lamellae free, membranous, crowded, greyish brown (M\&P 7A8 "Rose Grey"). Stipe 40-75(-100) ×3.5-4.5 mm, central, cylindrical, hollow, 
swollen at the base $(-6 \mathrm{~mm})$, white, with concolorous squamules near the annulus, turning yellow at the base on handing. Annulus membranous, fragile, pendant, sub apical, white. Context thin, fleshy. Basidiospores 4.3-5(-5.3) $\times 2.5-3.5 \mu \mathrm{m}$, on average $4.7 \times 3.1 \mu \mathrm{m}$, $\mathrm{Q}=(1.36-) 1.43-1.64(-1.81)$, short ellipsoid in side view, smooth, slightly thick-walled, brown. Basidia 15-20×6-7.5 $\mu \mathrm{m}$, clavate or sub fusoid, 2 to 4 sterigmata. Pleurocystidia absent. Cheilocystidia rare, $15-25 \times 7.5-10 \mu \mathrm{m}$, broadly clavate to sub piriform, thinwalled, hyaline. Pileipellis with ascendant hyphae, terminal elements $22-52 \times 6-10 \mu \mathrm{m}$, cylindrical, with violaceous-brown content. Hymenophoral trama regular. Clamp-connections absent.

Habitat: scattered on soil in tropical forest.

Material examined: BRAZIL. Pernambuco: Cabo de Santo Agostinho, Complexo do Gurjaú (Mata do Xangô), 19/VII/2004, F. Wartchow 17/2004 (URM 78680); Complexo do Gurjaú (Mata do Café), 3/VIII/2004, F. Wartchow 20/2004 (URM 78679); Complexo do Gurjaú (Mata do São Braz), 3/VIII/2004, F. Wartchow 21/2004 (URM 78678).

Distribution: Trinidad (Heinemann 1961), Kenya (Pegler 1977), Martinique (Pegler 1983). Brazil: São Paulo (Pegler 1997).

Remarks: This species of the subgenus Flavoagaricus Heinem. is recognized by the purplish squamules on the pileus and the size of the spores (Heinemann 1961). Maia et al. (2002) reported this species from Pernambuco State based on herbarium registers, but the exsiccate under the name Agaricus purpurellus (URM 75672) has basidiospores (5-)5.5-7.5(-8) ×3.5-4.8 $\mu \mathrm{m}$, similar in size to the spores of A. goossensiae Heinem. from Africa (Heinemann 1956; Pegler 1969), a species related to A. purpurellus (Pegler 1977).

3. Agaricus rufoaurantiacus Heinem., Kew Bull. 15: 242. 1961.

Fig. 9-12

Pileus $29 \mathrm{~mm}$, convex to broadly umbonate, surface with numerous verrucose orange-brown (M\&P $11 \mathrm{~L} 12$ "Orange Rufous") squamules on pale cream (M\&P 9B2 "Polar Bear") ground. Lamellae free, membranous, crowded, brown (M\&P 7A10 "New Coccoa, Natal Brown, Mahal+"). Stipe $45 \times 4 \mathrm{~mm}$, central, cylindrical, swollen at base $(-6 \mathrm{~mm})$, pallid cream, covered with numerous squamules, concolorous with pileal squamules. Veil forming dense squamules on pileus and stipe surface. Annulus persistent, pendant, membranous, sub apical, cream. Context thin, fleshy.
Basidiospores 4-5×2.5-3.7 $\mu \mathrm{m}$, on average $4.7 \times 3 \mu \mathrm{m}$, $\mathrm{Q}=(1.33-) 1.4-1.67(-1.81)$, ellipsoid to rarely ovoid in side view, smooth, slightly thick-walled, brown in deposit. Basidia 12.5-18×5-6.5 $\mu \mathrm{m}$, clavate to sub fusoid, 4 sterigmata. Pleurocystidia absent. Cheilocystidia $13.5-20 \times 5-7.5 \mu \mathrm{m}$, clavate to broadly clavate, thin-walled, hyaline. Pileipellis with trichoderm layer of narrow and parallel hyphae having segments $15-37 \times 5-8 \mu \mathrm{m}$, with light brown then orange-brown content. Hymenophoral trama regular. Clampconnections absent.

Habitat: solitary in sandy soil in a tropical forest.

Material examined: BRAZIL. Pernambuco: Recife, Mata de Dois Irmãos, 4/VII/2004, F. Wartchow 25/2004 (URM 78666).

Distribution: Trinidad (Heinemann 1961; Pegler 1983), Martinique (Pegler 1983). Brazil: São Paulo (Pegler 1997). This is the first record of A. rufoaurantiacus from Pernambuco.

Remarks: This species of the subgenus Lanagaricus Heinem., described from Trinidad (Heinemann 1961), has been recorded from the Lesser Antilles (Pegler 1983) and São Paulo State, Brazil (Pegler 1997) with slightly larger spores 4.5-5.5×3.6-4 $\mu \mathrm{m}$. Agaricus ochraceosquamulosus Heinem. differs in the colour of the pileal scales, its slightly larger basidiospores (5.1-5.7×3.6-4 $\mu \mathrm{m})$ and broader pileipellis hyphae (Heinemann 1961). The Schäffer's reaction was not tested in this specimen; in the type material the reaction is negative (Heinemann 1961). In the collections from the Lesser Antilles a positive reaction was observed on the material by Pegler (1983).

4. Leucoagaricus sulphurellus (Pegler) B.P. Akers in Akers et al., Mycotaxon 76: 48. 2000.

Leucocoprinus sulphurellus Pegler, Kew Bull. Add. Ser. 9: 420. 1983.

Fig. 17-21

Pileus (8-)13-21 mm wide, campanulate then plane, sulphur yellow (M\&P 10J1 "Sulphur Y, Citrus) with small greyish brown (M\&P 16A4 "Rose Taupe") squamules, with margin indistinctly sulcate. Lamellae free, membranous, close, sulphur yellow (M\&P 10J1 "Sulphur Y, Citrus), discolouring greenish blue when bruised. Stipe $28-40 \times 2.5-3.5 \mathrm{~mm}$, central, cylindrical, sometimes attenuate at base, glabrous, smooth, concolorous with pileus and lamellae. Annulus small and fragile, concolorous with stipe. Context thin, fleshy. Basidiospores $6.2-7.2 \times 3.7-5 \mu \mathrm{m}$, on average $6.6 \times 4.3 \mu \mathrm{m}, \mathrm{Q}=(1.39-) 1.5-1.76(-1.81)$, ellipsoid in side 

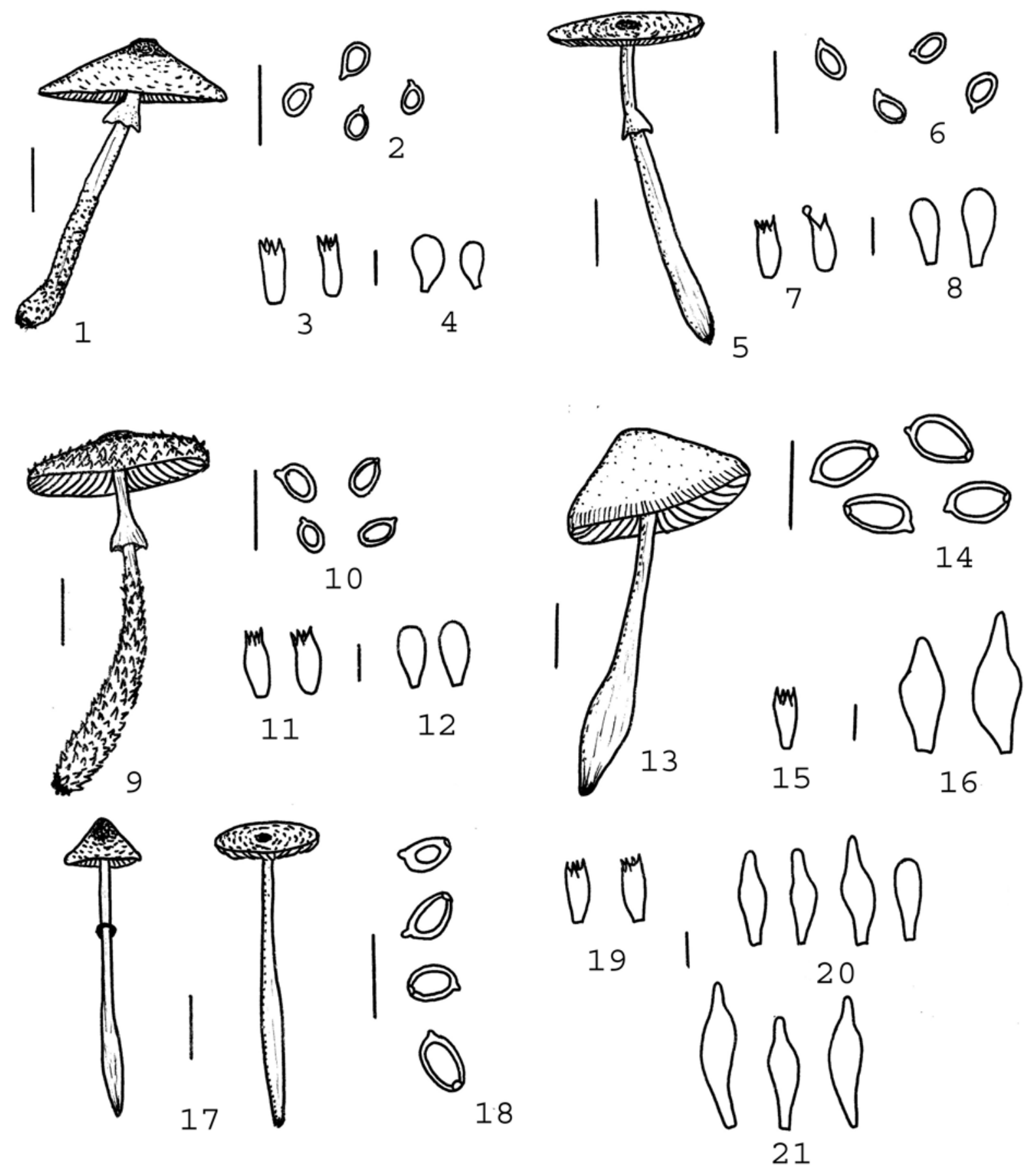

Figures 1-20. 1-4. Agaricus aff. parasilvaticus Heinem. 1. Basidioma. 2. Basidiospores. 3. Basidia. 4. Cheilocystidia. 5-8. Agaricus purpurellus (F.H. Møller) F.H. Møller. 5. Basidioma. 6. Basidiospores. 7. Basidia. 8. Cheilocystidia. 9-12. Agaricus rufoaurantiacus Heinem. 9. Basidioma. 10. Basidiospores. 11. Basidia. 12. Cheilocystidia. 13-16. Leucocoprinus cretaceus (Bull.: Fr.) Locq. 13. Basidioma. 14. Basidiospores. 15. Basidium. 16. Cheilocystidia. 17-21. Leucoagaricus sulphurellus (Pegler) B.P. Akers. 17. Basidiomata. 18. Basidiospores. 19. Basidia. 20. Cheilocystidia 21. Pleurocystidia. Scaly bar is $10 \mathrm{~mm}$ for the basidiomata and $10 \mu \mathrm{m}$ for microscopic features. 
view, dextrinoid, metachromatic, smooth, with small germ pore, thick-walled, hyaline. Basidia 15-18x 7-10 $\mu \mathrm{m}$, clavate, with 4 sterigmata. Pleurocystidia $30-50(-62) \times 8-12(-15) \mu \mathrm{m}$, fusoid-mucronate, thinwalled, hyaline. Cheilocystidia $23-37 \times 8-12 \mu \mathrm{m}$, inflatedclavate to occasionally fusoid, with sub mucronate to mucronate apex, thin-walled, hyaline. Pileipellis as cutis, with terminal elements (13-)15-35(-42)×5-10 $\mu \mathrm{m}$, cylindrical to clavate. Hymenophoral trama regular. Clamp-connections absent.

Habitat: solitary on soil in tropical forest.

Material examined: BRAZIL. Pernambuco: Recife, Mata de Dois Irmãos, 4/II/2004, L. Ryvarden \& F. Wartchow s.n. (URM 78662, HCB 18237); Cabo de Santo Agostinho, Complexo do Gurjaú (Mata do Café), 21/VI/2004, F. Wartchow 10/2004 (URM 78677).

Distribution: Lesser Antilles (Pegler 1983), Bolivia (Moreno-Arroyo et al. 2001), Colombia (VascoPalacios et al. 2005). Brazil: São Paulo (Pegler 1997). L. sulphurellus is reported for the first time in Pernambuco.

Remarks: This species is characterized by the sulphur yellow basidioma, the lamellae discolouring when bruising, size of the spores and the presence of pleurocystidia (Pegler 1983). Moreno-Arroyo et al. (2001) did not report pleurocystidia in "Leucocoprinus cf. sulphurellus" from Bolivia, which leaves open to question their assignment to L. sulphurellus. The presence of pleurocystidia in Leucoagaricus has also been reported in L. viridiflavoides B.P. Akers from North America (Akers et al. 2000), L. americanus (Peck) Vellinga and L. barssii (Zeller) Vellinga from Europe and North America (Vellinga 2000). L. pleurocystidiatus Migliozzi \& Testoni (2000) is probably a synonym of L. barssii (Vellinga personal correspondence).

5. Leucocoprinus cretaceus (Bull.: Fr.) Locq., Bull. Mens. Soc. Linn. Lyon 14: 93. 1945.

Agaricus cretaceus Bull., Herbier de la France 8: tab. 374. 1788.

Fig. 13-16

Pileus 14-30 mm wide, ovoid when young then broadly convex, umbonate in maturity, white, with numerous floccose squamules in young basidiomata (not abundant at maturity); margin sulcate. Lamellae free, membranous, sub close, white. Stipe $52-78 \times 3$ $4 \mathrm{~mm}$, central, fusiform bulbous $5.5-6.5 \mathrm{~mm}$ wide, white or cream, with floccose squamules and pseudorrhiza present. Annulus membranous, sub apical, white, fragmenting in older basidiomata. Context thin, fleshy. Basidiospores (5-)6.2-10×(4.5-)5-7 $\mu \mathrm{m}$, on average $9.4 \times 6 \mu \mathrm{m}, \mathrm{Q}=(1.4-) 1.5-1.75(-1.91)$, ellipsoid in side view, dextrinoid, metachromatic, smooth, thick-walled with germ pore, hyaline. Basidia 13-17.5×6-7 $\mu \mathrm{m}, 4$ sterigmata. Pleurocystidia absent. Cheilocystidia, e.g., $33 \times 17.5 \mu \mathrm{m}$, inflated-clavate, with long mucro, thinwalled, hyaline. Pileipellis with interwoven hyphae having terminal segments 40-105(-130)×8-22(-27) $\mu \mathrm{m}$, clavate to cylindrical, hyaline. Hymenophoral trama trabecular. Clamp-connections absent.

Habitat: sub gregarious in unidentified, living, dicotyledonous tree in tropical forest.

Material examined: BRAZIL. Pernambuco: Recife, Mata de Dois Irmãos, 4/II/2004, F. Wartchow s.n. (URM 78667, HCB 18240 as "Leucocoprinus cepaestipes").

Distribution: tropics (Baker \& Dale 1951; Vellinga 2004b), Europe (Josserand 1955; Candusso \& Lanzoni 1990). Brazil: Rio Grande do Sul (Sobestiansky 2005). This is the first record for Pernambuco.

Remarks: This tropical species, macroscopically characterized by floccose white squamules on the pileus and inflated fusiform bulbous stipe, is frequently reported as growing on greenhouse and compost heaps from Europe (Josserand 1955; Candusso \& Lanzoni 1990 as L. cretatus).

Two phenetically close species are known: Leucocoprinus squamulosus (Mont.) Pegler, with exannulate and non-inflated stipe (Pegler 1983), and L. cepistipes (J. Sowerby: Fr.) Pat., with ochraceous to light brown squamules on pileus surface (Candusso \& Lanzoni 1990). This species was initially identified as L. cepistipes sensu Dennis (1952).

\section{Leucocoprinus fragilissimus (Ravenel) Pat., Essai} Taxon. 171. 1900.

Hiatula fragilissima Ravenel in Berkeley \& Curtis, Ann. Mag. Nat. Hist. ser II 12: 422.1853.

Fig. 22-24

Basidiomata extremely fragile. Pileus 5-24 mm wide, convex then plane and depressed, yellow (M\&P 9D1), cracking into small squamules on white ground, translucent, except at disc, plicate striate, subdeliquescent. Lamellae free, membranous, moderately close, white. Stipe 49-91×1-2 mm, central, cylindrical, glabrous, yellow. Context membranous except in disc. Annulus persistent, attached to upper half of stipe, membranous, yellow. Basidiospores 10-12.5× 7.5-8.8 $\mu \mathrm{m}$, on average $11.3 \times 7.8 \mu \mathrm{m}, \mathrm{Q}=1.33-1.67$, broadly ellipsoid with short cylindrical region terminated 
by broad germ pore in side view, strongly dextrinoid, metachromatic, smooth, thick-walled, hyaline. Hymenial structure not recovered. Pileipellis with loose sphaerocysts $28-40 \times 20-35 \mu \mathrm{m}$ and cylindrical elements 45-100×7.5-15 $\mu \mathrm{m}$, with all elements hyaline.

Habitat: solitary on soil and leaves in tropical forest.

Material examined: BRAZIL. Pernambuco: Recife, Mata de Dois Irmãos, 4/II/2004, B.T. Goto et al. s.n. (URM 78665).

Distribution: Southern parts of North America (Morgan 1907; Smith \& Weber 1982; Kimbrough 2000), Sri Lanka (Pegler 1972; 1986), Galapagos Islands (Reid et al. 1981), Lesser Antilles (Pegler 1983), Japan (Hongo 1986), Italy (Ballero \& Contu 1991), Vietnam (Patouillard 1892; Yang 2000). Brazil: Rio Grande do Sul (Theissen 1912; Albuquerque et al. 2006), Rondônia (Capelari \& Maziero 1988), São Paulo (Pegler 1997). This is the first record for Pernambuco.

Remarks: This is a very delicate species, with a widespread tropical distribution, easily recognized by its yellowish squamules, sub-deliquescent basidioma and size and shape of the basidiospores (Pegler 1983).

7. Lepiota elaiophylla Vellinga \& Huijser, Bol. Gr. Micol. G. Bres. 40: 462. 1997.

Fig. 25-29

Pileus 13-15 mm wide, plane-convex with small but conspicuous umbo, brown (M\&P 14F8 "Mosul") over disc, otherwise brown surface disrupting into small squamules on cream (M\&P 9D2 "Cream") ground, with remnants of veil on margin. Lamellae free, membranous, close, lemon yellow (M\&P 19K2 "CitronGreen”). Stipe 22-23×1-2.5 mm, central, cylindrical, concolorous with pileus, with brown (M\&P 14F8 "Mosul") squamules, lacking true annulus, white rhizomorphs present. Context thin, fleshy. Smell sweetish. Basidiospores 6-7.5×2.5-3.8 $\mu \mathrm{m}$, on average $6.8 \times 3.5 \mu \mathrm{m}, \mathrm{Q}=(1.5-) 1.67-2.5(-3)$, ellipsoid to subcylindrical in side view, some with slight suprahilar depression, dextrinoid, thin-walled, hyaline. Basidia 1520×6-7.5 $\mu \mathrm{m}$, clavate, 4 sterigmata. Pleurocystidia absent. Cheilocystidia $17.5-27.5 \times 5-10 \mu \mathrm{m}$, clavate to occasionally sub-fusoid, thin-walled, hyaline. Pileipellis a trichoderm, with terminal elements 30-190x 8.5-17 $\mu \mathrm{m}$, cylindrical to sub-fusoid, erect to sub-erect, moderately thick-walled, with yellowish brown intracellular content. Hymenophoral trama sub-regular. Clamp-connections present.

Habitat: solitary on soil among litter in tropical forest.

Material examined: BRAZIL. Pernambuco: Recife, Mata de Dois Irmãos, 31/VII/2003, I.G. Baseia et al. s.n. (URM 78654).

Distribution: in greenhouses in Europe (Breitenbach \& Kranzlin 1995 as L. xanthophylla; Vellinga \& Huijser 1997; Pidlich-Aigner et al. 2001), probably East Africa (Pegler 1977, but see Vellinga \& Huijser 1997). Brazil: Paraná (de Meijer 2006). This species is reported for the first time from Pernambuco.

Remarks: The material differs from Lepiota xanthophylla P.D. Orton mainly by the absence of a layer of clavate elements in the pileipellis (Vellinga \& Huijser 1997). The Brazilian collection agrees with the description of L. xanthophylla sensu Pegler (1977), particularly in spore size. Vellinga \& Huijser (1997) suggested that Pegler's East African material may be L. elaiophylla Vellinga \& Huijser, mainly by the shape of the cheilocystidia and size and shape of the pileipellis hyphae.

Other species with yellowish lamellae and clamps on hyphae occur in the Neotropics: L. parvispora Dennis from Venezuela (Dennis 1961), L. flavidocana Pegler from the Lesser Antilles (Pegler 1983) and $L$. xanthophylloides Singer from Pará State, North Brazil (Singer 1973 as L. xanthophylla). However, all of them are reported to bear spores predominantly or entirely lesser than $6 \mu \mathrm{m}$ long. In L. ochraceolamellata Dennis, clamp-connections are absent (Dennis 1961). Other species cited by Vellinga \& Huijser (1997) are reported by them as poorly documented, mostly regarding to the presence or absence of clampconnections and structure of the pileipellis.

Recent molecular studies report that Lepiota elaiophylla, L. subincarnata J.E. Lange and L. brunneoincarnata Chodat \& Martín belong to a group containing amanitin (Vellinga 2003b), the same mycotoxin found in Amanita phalloides and allies (Lampe 1979).

Lepiota elaiophylla was previously reported from greenhouses (Vellinga \& Huijser 1997). In this work, it is reported for the second time in a natural habitat from the Neotropics.

8. Lepiota erythrosticta (Berk. \& Broome) Sacc., Syll. Fung. 5: 62. 1887.

Agaricus erythrostictus Berk. \& Broome, Journ. Linn.

Soc. Bot. 11: 508. 1871.

Fig. 30-34

Pileus 4-14 mm wide, subglobose to plane, obtusely umbonate; pink (M\&P 3C10 "Congo Pink+") over disc, otherwise with surface disrupting into small squamules on white ground; margin entire, not sulcate. Lamellae free, membranous, crowded, white. Stipe $24-38 \times$ 
2-3 mm, cylindrical, with pink (M\&P 6L9 "Garnet Brown") squamules on white surface; rhizomorphs present. Annulus ephemeral, sub-apical. Basidiospores $6-8.3 \times 2.5-3.5 \mu \mathrm{m}$, on average $7.5 \times 3 \mu \mathrm{m}$, $\mathrm{Q}=(1.5-) 1.76-3(-3.5)$, spurred, with truncate base, dextrinoid, smooth, thin-walled, hyaline. Basidia 15-20 $\times 5-6.2 \mu \mathrm{m}$, clavate, 2 or 4 sterigmata. Pleurocystidia absent. Cheilocystidia inconspicuous, 30-38×6-10 $\mu \mathrm{m}$, clavate or fusoid, thin-walled, hyaline. Pileipellis as trichoderm, with terminal elements $30-105 \times 8-15(-17.5) \mu \mathrm{m}$, fusoid, clavate to cylindrical, sometimes capitate, ranging from having light yellowish brown intracellular pigment to being nearly colourless, with wall slightly thickened. Hymenophoral trama regular. Clamp-connections present.

Habitat: solitary on soil in tropical forest.

Material examined: BRAZIL. Pernambuco: Recife, Mata de Dois Irmãos, 4/II/2004, T.B. Gibertoni et al. s.n. (URM 78661; HCB 18235).

Additional material examined: BRAZIL. Pernambuco: Recife, Campus UFPE, 5/VI/1995, J. Kimbrough \& J. Kimbrough s.n. (URM 75744).

Distribution: Sri Lanka (Pegler 1972; 1986), Papua New Guinea (Horak 1980), Trinidad (Dennis 1952), Martinique, Guadeloupe, Trinidad and West Africa (Pegler 1983). Brazil: Pernambuco (Kimbrough et al. 1995), Paraná (de Meijer 2001).

Remarks: Lepiota erythrosticta belongs to the group with Lepiota having spurred spores and elongate elements in the pileipellis (Horak 1980). Pereira (2000) reported five species with this spore shape, all from southern Brazil, and two have similar pileus surface colour: L. pyrrhaes (Berk. \& Broome) Sacc., with shorter squamules hyphae (Horak 1980); and L. apicepigmentata A.B. Pereira with filiform hyphae having dark pigment at their apex (Pereira 1998; 2000).

The purplish colour indicated by Dennis (1952) and Pegler $(1972 ; 1983 ; 1986)$ for L. erythrosticta, was not observed in the Brazilian material, but Horak (1980) reported that the colour of the cap surface turns pink in mature basidiomata.

Horak (1980) did not accept the distribution of L. erythrosticta from the Caribbean, as indicated by Dennis (1952), restricting the present species to Indomalaya and Australasia. Nevertheless, Pegler (1983) reported this species from the Lesser Antilles, and Kimbrough et al. (1995) and de Meijer (2001) reported it from Brazil, confirming the occurrence of this species in the Neotropics.
9. Micropsalliota brunneosperma (Singer) Pegler in Pegler \& Rayner, Kew Bull. 23: 369. 1969.

Lepiota brunneosperma Singer, Lilloa 25: 279. 1952.

Fig. 35-39

Entire basidioma dark purplish brown in dried specimens. Pileus $32 \mathrm{~mm}$ wide, convex, umbonate, with surface purple (M\&P 3G1 "Corinthian Pink") over disc, disrupting into very small squamules on greyish brown (M\&P 12A2 "Moonmist") background, with margin not sulcate and not striate. Lamellae free, membranous, close, brown (M\&P 7A12 "Cochin, Moccasin+, Argus Brown"). Stipe $56 \times 4 \mathrm{~mm}$, central, cylindrical above, attenuate at base, pale cream (M\&P 9B2 "Polar Bear"), with dark brown (M\&P 8E9 "Negro") fibrillose squamules, mainly at base. Annulus persistent, pale cream (M\&P 9B2 "Polar Bear") with brown (M\&P 8A10 "Sepia") margin, membranous. Context thin, fleshy, unchanging. Basidiospores 4.6-6.2×2.5-4 $\mu \mathrm{m}$, on average $5.2 \times 3.2 \mu \mathrm{m}, \mathrm{Q}=(1.25-) .47-1.92(-2)$, amygdaliform in side view, smooth, with wall slightly thickening at apex, dark green in $\mathrm{KOH}$. Basidia 13.5-17.5 $\times 5-6 \mu \mathrm{m}$, clavate, 4 sterigmata. Pleurocystidia absent. Cheilocystidia abundant, 25-50×2.5-5.5(-6) $\mu \mathrm{m}$, predominantly fusoid, some ventricose, capitate (3.5-6 $\mu \mathrm{m}$ width), thin walled, hyaline. Pileipellis with erect hyphae, with terminal elements $25-95 \times$ 5-17(-20) $\mu \mathrm{m}$ and having sub-acute apex and purplishbrown contents. Hymenophoral trama regular. Clampconnections absent.

Habitat: solitary, on soil in a tropical forest.

Material examined: BRAZIL. Pernambuco: Recife, Mata de Dois Irmãos, 4/II/2004, B.T. Goto et al. s.n. (URM 78658).

Distribution: Argentina (Singer \& Digilio 1952; Pegler 1977), Kenya (Pegler \& Rayner 1969), Uganda, Trinidad (Pegler 1977), Galapagos Islands (Reid et al. 1981). This is the first record of M. brunneosperma from Brazil.

Remarks: Heinemann (1983) placed this complex species in two distinct groups: Group IV, with pileus (10-)20-70 mm wide, and Group III with smaller pileus, 2-20(-30) $\mathrm{mm}$ wide. He also considered the allied Micropsalliota cephalocystis (Heinem.) Heinem. as an independent species, in Group III. The latter species was originally described as Agaricus cephalocystis Heinem. from Trinidad, which was considered as belonging to the subgenus Conioagaricus Heinem. It was characterized by a delicate and sub-membranous pileus, basidiospores 5.3-6.5×3.3-3.8 $\mu \mathrm{m}$, and capitate cheilocystidia 25-35×4-5.5 $\mu$ m (Heinemann 1961). 

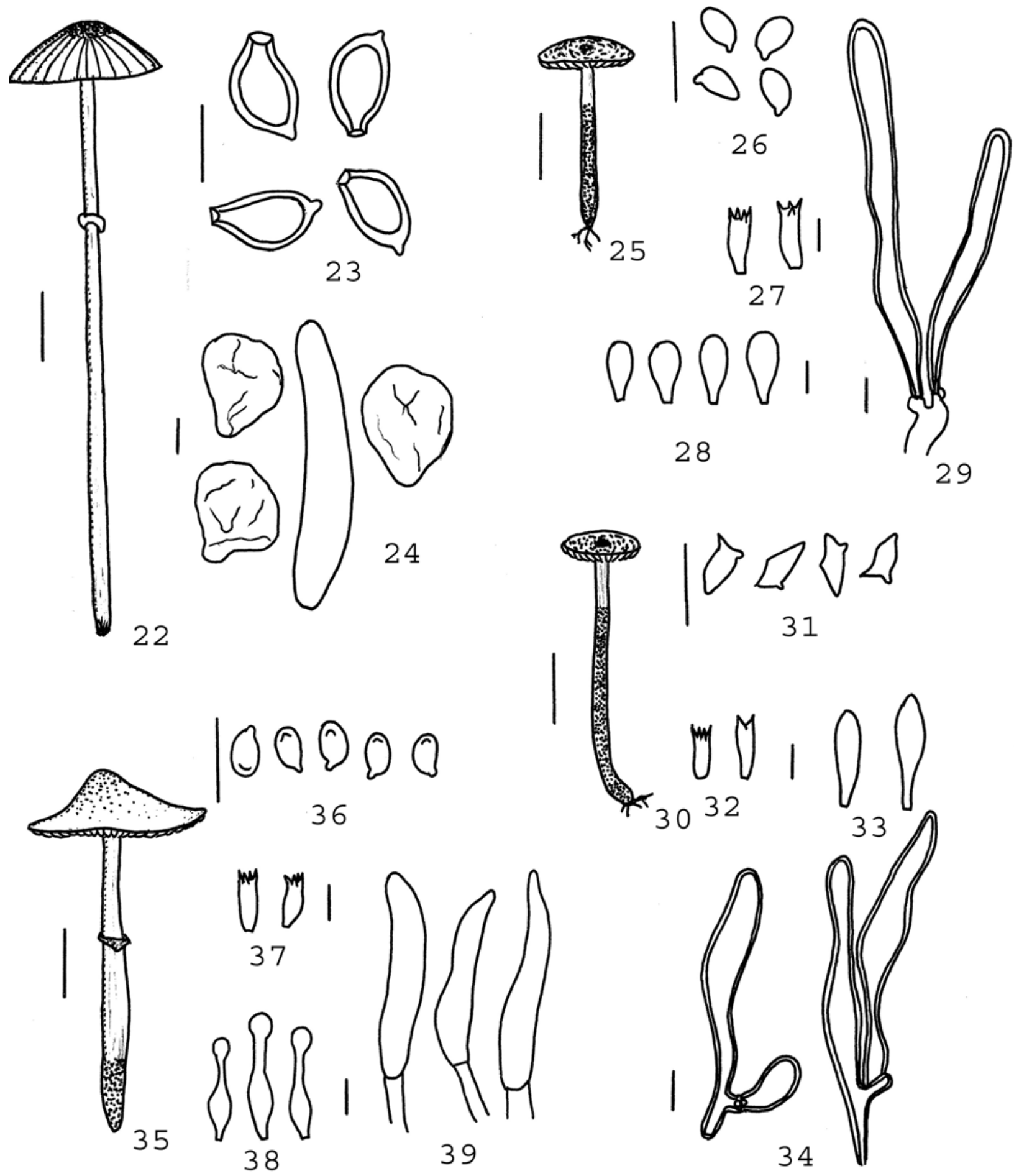

Figures 22-43. 22-24. Leucocoprinus fragilissimus (Ravenel) Pat. 22. Basidioma. 23. Basidiospores. 24. Elements of the pileipellis. 25-29. Lepiota elaiophylla Vellinga \& Huijser. 25. Basidioma. 26. Basidiospores. 27. Basidia. 28. Cheilocystidia. 29. Elements of the pileipellis. 30-34. Lepiota erythrosticta (Berk. \& Broome) Sacc. 30. Basidioma. 31. Basidiospores. 32. Basidia. 33. Cheilocystidia. 34. Elements of the pileipellis. 35-39. Micropsalliota brunneosperma (Singer) Pegler. 35. Basidioma. 36. Basidiospores. 37. Basidia. 38. Cheilocystidia. 39. Elements of the pileipellis. Scaly bar is $10 \mathrm{~mm}$ for the basidiomata and $10 \mu \mathrm{m}$ for microscopic features. 
Pegler (1977) regarded this species as a synonym of M. brunneosperma. Singer described the dark-spored Lepiota brunneosperma as having basidiospores 5.8-6.5×3.7-4.4 $\mu \mathrm{m}$ and large capitate cheilocystidia, 37-45×3.5-5.8 um (Singer \& Digilio 1952).

Our collection has narrower basidiospores than M. brunneosperma according to Heinemann's key (1989); but the size and shape of the cystidia, the thick wall difficult to discern at the apex of the spores, the dark colour of the pileus and the squamules of the stipe all support our determination of the Brazilian material.

Other species of Micropsalliota occur in the Americas: M. vinaceoumbrinus (A.H. Sm.) Heinem. from the U.S.A. has broader basidiospores, 6.27.3×4.8-5.4 um (Smith 1944); M. violaceosquamulosus (R.E.D. Baker \& W.T. Dale) Heinem. from Trinidad \& Tobago has a densely scaly stipe, brown basidiospores and cylindrical cheilocystidia (Heinemann 1961); M. purpurea Singer from Ecuador has much smaller basidiospores, 3.5-4.2×2.5 $\mu \mathrm{m}$ (Singer 1978); M. cinnamomeopalida Singer from Costa Rica (Singer \& Gómez 1982) and similar taxa reported from India as M. cf. cinnamomeopalida lacks dark purplish colour on the pileus (Heinemann \& Leelavathy 1991); the basidiospores of $M$. roseovinacea from Martinique have a homogeneous wall and cheilocystidia that are short cylindrical and capitate (Pegler 1983); M. cardinalis Heinem. from Argentina and M. pruinosa Heinem. from Rio de Janeiro State, Brazil, do not have pileus more than $10 \mathrm{~mm}$ wide (Heinemann 1989); M. heinemanniana Guzm.-Dáv., from Mexico has pleurocystidia (Guzmán-Dávalos 1992); and M. subalpina Guzm.-Dáv. \& Heinem., also from Mexico, has a slender basidioma and a cream to chocolate-brown pileus (Guzmán-Dávalos \& Heinemann 1994).

As observed, Micropsalliota has a wide distribution in tropical and temperate America. Other species have been recorded for Brazil: M. arginea (Berk. \& Broome) Pegler \& Rayner, M. cfr. campestroides (Heinem.) Heinem. and M. cephalocystis from Paraná State (Heinemann 1993), and M. roseovinacea from São Paulo State (Pegler 1997).

Recently, Maia et al. (2002), based on material deposited in URM, cited " $M$. roseovinaceus Pegler" as occurring in our region of interest. However, the exsiccatum revised (URM 75654) has basidiospores that are 5.3-7.4×4-4.5 $\mu \mathrm{m}$, dextrinoid, metachromatic endosporium, lack a germ pore and are hyaline. In addition, the pileal surface is neither sulcate nor striate. Hence, the revised specimen is a typical Leucoagaricus and is necessary to exclude $M$. roseovinacea from the list of species known from Pernambuco.

\section{Acknowledgements}

The senior author is grateful to Dr. Leonor C. Maia for helping and support, Dr. Else C. Vellinga, Dr. Laura Guzmán-Dávalos for valuable comments about the manuscript; Dr. Reinhardt Agerer, Dr. Marcel Bon, Dr. Gastón Guzmán, Dr. Roy E. Halling, Mr. André A.R. de Meijer and Dr. Vicenzo Migliozzi for sending literature; Dr. Iuri G. Baseia, Dr. Leif Ryvarden, Dr. Tatiana B. Gibertoni, Mr. Bruno T. Goto and M.Sc. Sueli A.G. Soares for helping with the collections. Dr. Rodham E. Tulloss and Dr. Paul M. Kirk are acknowledged for English improvement. Thanks also to M.Sc. Vagner G. Cortez for preparation of the plates. This work was supported by CNPq.

\section{References}

Agerer, R. 2002. Rhizomorph structures confirm the relationship between Lycoperdales and Agaricaceae (Hymenomycetes, Basidiomycota). Nova Hedwigia 75: 367-385.

Akers, B.P.; Angels, S.A. \& Kimbrough. J.W. 2000. Leucoagaricus viridiflavoides, a new species from Florida, with notes on related taxa. Mycotaxon 76: 39-50.

Albuquerque, M.P.; Victoria, F.C. \& Pereira, A.B. 2006. Ecologia e distribuição do gênero Leucocoprinus Pat. no Rio Grande do Sul, Brasil. Acta Biologica Leopoldensia 28: 11-16.

Baker, R.E.D. \& Dale, W.T. 1951. Fungi of Trinidad and Tobago. Mycological Papers 33: 1-123.

Ballero, M. \& Contu, M. 1991. Caratteristiche e fondamenti sistematici per l'inquadramento dei generi delle Lepiotaceae Roze ex Van Overem (Basidiomycetes, Agaricales) riscontrati in Sardegna. Candollea 46: 475-483.

Bon, M. 1993. Famille Lepiotaceae Roze ex Overeen. Documents Mycologiques 22: 27-32.

Bononi, V.L.R. 1992. Fungos macroscópicos de Rio Branco, Acre, Brasil. Hoehnea 19: 31-37.

Bononi, V.L.R.; Trufem, S.F.B. \& Grandi, R.A.P. 1981a. Fungos macroscópicos do Parque Estadual das Fontes do Ipiranga, São Paulo, Brasil, depositados no Herbário do Instituto de Botânica de São Paulo. Rickia 9: 37-53.

Bononi, V.L.R.; Autuori, M. \& Rocha, M.B. 1981 b. Leucocoprinus gongylophorus (Möller) Heim, o fungo do formigueiro de Atta sexedens rubropilosa. Rickia 9: 93-97.

Bononi, V.L.R.; Mucci, E.S.F.; Yokomizu, N.K.S. \& Guzmán, G. 1984. Agaricales (Basidiomycetes) do Parque Estadual de Campos do Jordão, SP, Brasil. Rickia 11: 85-89. 
Breitenbach, J. \& Kranzlin, F. 1995. Fungi from Switzerland. Agarics. $2^{\text {nd }}$ part. IV. Lucerne, Mykologia Lucerne.

Candusso, M. \& Lanzoni, G. 1990. Lepiota s.l. Fungi Europaei IV. Saronno, Libreria Editrice Giovanna Biella.

Capelari, M. \& Gimenes, L.J. 2004. Leucocoprinus brunneoluteus, uma nova espécie de Agaricaceae. Hoehnea 31: 331-335.

Capelari, M. \& Maziero, R. 1988. Fungos macroscópicos do Estado de Rondônia, região dos Rios Jaru e Ji-Paraná. Hoehnea 15: 28-36.

Capelari, M.; Rosa, L.F. \& Lachance, M.-A. 2006. Description and affinities of Agaricus martineziensis, a rare species. Fungal Diversity 21: 11-18.

Dennis, R.W.G. 1952. Lepiota and allied genera in Trinidad, British West Indies. Kew Bulletin 7: 459-499.

Dennis, R.W.G. 1961. Fungi venezuelani. IV. Agaricales. Kew Bulletin 15: 67-156.

Franco-Molano, A.E. 1995. Observations on Rugosospora in the Neotropics. Mycologia 87: 574-578.

Freeman, A.E.H. 1979. Agaricus in North America: type studies. Mycotaxon 8: 1-49.

Grandi, R.A.P.; Guzmán, G. \& Bononi, V.L.R. 1984. Adições às Agaricales (Basidiomycetes) do Parque Estadual das Fontes do Ipiranga, São Paulo, SP, Brasil. Rickia 11: 27-33.

Guzmán, G.; Bandala, V.M.; Montoya L. \& Saldarriaga, Y. 1989. Nuevas evidências sobre las relaciones micoflorísticas entre África y el neotrópico. El género Rugosospora Heinem. (Fungi, Agaricales). Brenesia 32: 107-112.

Guzmán-Dávalos, L. 1992. First record of the genus Micropsalliota (Basidiomycotina, Agaricaceae) in Mexico. Mycotaxon 43: 199-205.

Guzmán-Dávalos, L. \& Heinemann, P. 1994. Micropsalliota subalpina sp. nov. (Agaricaceae) from Mexico. Bulletin du Jardin Botanique National de Belgique 63: 195-199.

Heim, R. 1957. A propôs du Rozites gongylophora A. Möller. Revue de Mycologie 22: 293-299.

Heinemann, P. 1956. Champignons récoltés au Congo Belge par Madame M. Goossens-Fontana II. Agaricus Fr. ss. Bulletin du Jardin Botanique de l'État de Bruxelles 26 : 1-136.

Heinemann, P. 1961. Agarici Austro-Americani I. Agaricus of Trinidad. Kew Bulletin 15: 231-248.

Heinemann, P. 1962. Agarici Austro-Americani. IV. Quatre Agaricus du Venezuela. Bulletin du Jardin Botanique de l'État de Bruxelles 32: 155-161.

Heinemann, P. 1977. Essai d'une clé de détermination des genres Agaricus et Micropsalliota. Sydowia 30: 6-37.

Heinemann, P. 1983. Cle de détermination de Micropsalliota (Agaricaceae) et descrption de deux espèces nouvelles. Bulletin du Jardin Botanique National de Belgique 53: 85-95.

Heinemann, P. 1989. Le genre Micropsalliota en Amérique tropicale et subtropicale. Bulletin du Jardin Botanique National de Belgique 59: 459-466.

Heinemann, P. 1993. Agarici Austroamericani VIII. Agariceae des régions intertropicales d'Amérique du Sud. Bulletin du Jardin Botanique National de Belgique 62: 355-384.
Heinemann, P. \& Leelavathy, K.M. 1991. The genus Micropsalliota (Agaricaceae) in Kerala State, India. Mycological Research 95: 341-346.

Heinemann, P. \& de Meijer, A.A.R. 1996. The status of Volvolepiota Singer. Bulletin du Jardin Botanique National de Belgique 65: 405-412.

Hongo, T. 1986. On the Agaricaceae of Japan. Transactions of the Mycological Society of Japan 27: 99-107.

Horak, E. 1980. On Australasian species of Lepiota S.F. Gray (Agaricales), with spurred spores. Sydowia 33: 111-144.

Jezek, B. 1973. Nekolik ukazek brasilskich hub. Casopis Ceskoslovenskych Houbarù, Mykologicky Sbornik 50: 75-79.

Johnson, J. \& Vilgalys, R. 1998. Phylogenetic systematic of Lepiota sensu lato based on nuclear large subunit rDNA evidence. Mycologia 90: 971-979.

Josserand, M. 1955. Notes critiques sur quelques champignons de la Région Lyonnaise. Bulletin de la Société Mycologique de France 71: 66-125.

Kimbrough, J.W. 2000. Common Florida Mushrooms. Gainesville, University of Florida - Institute of Food and Agricultural Sciences.

Kimbrough, J.W.; Alves, M.H. \& Maia, L.C. 1994/1995. Basidiomycetes saprófitos em troncos vivos e em folhedo de "sombreiro" (Clitoria fairchildianai [Benth.] Howard). Biologica Brasilica 6: 51-56.

Kirk P.M.; Cannon P.F.; David J.C. \& Stalpers J.A. 2001. Ainsworth \& Bisby's Dictionary of Fungi. $9^{\text {th }}$ ed. Wallingford, CAB International.

Lampe, K.F. 1979. Toxic Fungi. Annual Review of Pharmacology and Toxicology 19: 85-104.

Maerz, A.J. \& Paul, M.R. 1950. A Dictionary of Color. $2^{\text {nd }}$ ed. New York, McGraw-Hill Company.

Maia, L.C.; Yano-Melo, A.M. \& Cavalcanti, M.A.Q. 2002. Diversidade de Fungos no Estado de Pernambuco. Pp. 15-50. In: M. Tabarelli \& J.M.C. Silva (eds.). Diagnóstico da Biodiversidade de Pernambuco. Recife, Ed. Massangana.

de Meijer, A.A.R. 2001. Mycological work in the Brazilian state of Paraná. Nova Hedwigia 72: 105-159.

de Meijer, A.A.R. 2006. Preliminary list of the macromycetes from the Brazilian State of Paraná. Boletim do Museu Botânico Municipal 68: 1-55.

Migliozzi, V. \& Testoni, A. 2000. Leucoagaricus pleurocystidiatus sp. nov. Descrizione di una nuova specie limite del genere leucoagaricus e tipificazione della sezione Cystidiosi sect. nova. Rivista di Micologia 2: $227-234$.

Moncalvo, J.M.; Vilgalys, R.; Redhead, S.A.; Johnson J.E.; James, T.Y.; Aime, M.C.; Hofstetter, V.; Verduin, S.J.W.; Larsson, E.; Baroni, T.J.; Thorn R.G.; Jacobsson, S.; Clémençon, H. \& Miller Jr., O.K. 2002. One hundred and seventeen clades of euagarics. Molecular Phylogenetic and Evolution 23: 357-400.

Montagne, J.P.F.C. 1856. Septième centurie de plantes cellulaires nouvelles, tant indigènes qu' exotiques. Annales des Sciences Naturélles, Botanique Série 4: 333-374. 
Moreno-Arroyo, B.; Díaz, A.O.; Esteves-Raventós, F. \& Gómez, J. 2001. Brevi note tassonimiche su alcuni macromiceti della Bolivia. Bolletino del Gruppo Micologico G. Bresadola, Nuova Serie 44: 45-62.

Morgan, A.P. 1907. North American species of Lepiota. Journal of Mycology 13: 1-18.

Muchovej, J.J.; Della Lucia, I.M. \& Muchovej, R.M.C. 1991. Leucoagaricus weberi sp. nov. from a live nest of leafcutting ants. Mycological Research 95: 1308-1311.

Murrill, W.A. 1918. The Agaricaceae of tropical North America. VIII. Mycologia 10: 62-85.

Patouillard, N. 1892. Champignons noveau ExtraEuropéens. Bulletin de la Société Mycologique de France 8: 46-50.

Pegler, D.N. 1969. Studies on African Agaricales: II. Kew Bulletin 23: 217-248.

Pegler, D.N. 1972. A revision of the genus Lepiota from Ceylon. Kew Bulletin 27: 155-202.

Pegler, D.N. 1977. A preliminary Agaric flora of East Africa. Kew Bulletin Additional Series 6: 1-615.

Pegler, D.N. 1983. Agaric Flora of the Lesser Antilles. Kew Bulletin Additional Series 9: 1-668.

Pegler, D.N. 1986. Agaric Flora of Sri Lanka. Kew Bulletin Additional Series 12: 1-514.

Pegler, D.N. 1987. A revision of the Agaricales of Cuba 2. Species described by Earle and Murrill. Kew Bulletin 42: 855-888.

Pegler, D.N. 1990. Agaricales of Brazil described by J. P. F. C. Montagne. Kew Bulletin 45: 161-177.

Pegler, D.N. 1997. The Agarics of São Paulo, Brazil. Kew, Royal Botanical Gardens.

Pegler, D.N. \& Rayner, R.W. 1969. A contribution of the agaric flora of Kenya. Kew Bulletin 23: 347-412.

Pereira, A.B. 1998. Espécies novas do gênero Lepiota (Agaricaceae) do sul do Brasil. Iheringia, Série Botânica 51: 227-247.

Pereira, A.B. 2000. Contribuição ao conhecimento do gênero Lepiota no Brasil. I. Pesquisas, Série Botânica 50: 27-77.

Pidlich-Aigner, H.; Hausknecht, A. \& Scheuer, C. 2001. Annotated list of macromycetes found in the greenhouses of the Botanic Garden of the Institute of Botany in Graz (Austria), 1998-2001. Fritschiana 32: 49-61.

Raithelhuber, J. 1987a. Die Gattung Leucocoprinus in ABCStaden. Metrodiana 15: 35-44.

Raithelhuber, J. 1987b. Die Gattung Macrolepiota in Südamerika. Metrodiana 15: 59-71.

Raithelhuber, J. 1988. Typenstudien an exsikkaten aus südamerikanischen herbarien. Metrodiana 16: 5-29.

Redhead, S.A.; Vilgalys, R.; Moncalvo, J.-M.; Johnson, J. \& Hopple Jr., J.S. 2001. Coprinus Pers. and the disposition of Coprinus species sensu lato. Taxon 50: 203-241.

Reid, D.A.; Pegler, D.N. \& Spooner, B.M. 1981. An annotated list of the Fungi of the Galapagos Islands. Kew Bulletin 35: 847-892.

Rick, J. 1961. Basidiomycetes Eubasidii in Rio Grande do Sul - Brasilia. 5. Iheringia, Série Botânica 8: 296-450.
Secretaria Estadual de Ciência, Tecnologia e Meio Ambiente. 2001. Diagnóstico das Reservas Ecológicas: Região Metropolitana do Recife. Recife, Secretaria Estadual de Ciência, Tecnologia e Meio Ambiente do Estado de Pernambuco.

Singer, R. 1953. Type studies on Basidiomycetes VI. Lilloa 26: 57-159.

Singer, R. 1973. Diagnoses fungorum novorum Agaricalium III. Beiheft zur Sydowia 7: 1-106.

Singer, R. 1978. Interesting and new species of Basidiomycetes from Ecuador. II. Nova Hedwigia 29: 1-98.

Singer, R. 1986. The Agaricales in Modern Taxonomy. $4^{\text {th }}$ ed. Stuttgart, Koeltz Scientific Books.

Singer, R. 1989. New taxa and new combinations of Agaricales (Diagnoses Novorum Agaricalium IV). Fieldiana, Botanica 21: 1-133.

Singer, R. \& Aguiar, I.J.A. 1986. Litter decomposing and ectomycorrhizal Basidiomycetes in an Igapó Forest. Plant Systematic and Evolution 153: 107-117.

Singer, R. \& Digilio, A.P.L. 1952 ('1951’). Pródromo a la flora agaricina Argentina. Lilloa 25: 5-462.

Singer, R. \& Gómez, L.D. 1982. Basidiomycetes of Costa Rica. I. Brenesia 19/20: 31-47.

Smith, A.H. 1944. New North American agarics. Mycologia 36: $242-262$

Smith, A.H. 1973. Agaricales and related secotioid Gasteromycetes. Pp. 421-450. In: G.C. Ainsworth; F.K. Sparrow \& A.S. Sussman. The Fungi: An Advanced Treatise. IV B. New York, Academic Press.

Smith, H.V. \& Weber, N.S. 1982. Selected species of Leucocoprinus from the south-eastern United States. Contributions from the University of Michigan Herbarium 15: 297-309.

Sobestiansky, G. 2005. Contribution to a Macromycete survey of the states of Rio Grande do Sul and Santa Catarina in Brazil. Brazilian Archives of Biology and Technology 48: 437-457.

Spielmann, A.A. \& Putzke, J. 1998. Leucoagaricus gongylophorus (Agaricales, Basidiomycota) em ninho ativo de formigas Attini (Acromyrmex asperus). Caderno de Pesquisas, Série Botânica 10: 27-36.

Theissen, F. 1912. Hymenomycetes Riograndenses. Brotéria, Série Botânica 10: 1-24.

Vasco-Palacios, A.M.; Franco-Molano, A.E.; LópezQuinteros, C.A. \& Boekhout, T. 2005. Macromicetos (Ascomycota, Basidiomycota) de la región del medio Caquetá, departamentos de Caquetá y Amazonas (Colombia). Biota Colombiana 6: 127-140.

Vellinga, E.C. 2000. Notes on Lepiota and Leucoagaricus. Type studies on Lepiota magnispora, Lepiota barssii, and Agaricus americanus. Mycotaxon 76: 429-438.

Vellinga, E.C. 2002. New combinations in Chlorophyllum. Mycotaxon 83: 415-417.

Vellinga, E.C. 2003a. Chlorophyllum and Macrolepiota (Agaricaceae) in Australia. Australian Systematic of Botany 16: 361-370. 
Vellinga, E.C. 2003b. Phylogeny of Lepiota (Agaricaceae) Evidence from nrITS and nrLSU sequences. Mycological Progress 2: 305-322.

Vellinga, E.C. 2004a. Genera in the family Agaricaceae: evidence from nrITS and nrLSU sequences. Mycological Research 10: 352-377.

Vellinga, E.C. 2004b. Ecology and distribution of lepiotaceous fungi (Agaricaceae) - A Review. Nova Hedwigia 78: 273-299.

Vellinga E.C. \& Huijser, H.A. 1997. Lepiota xanthophylla and its greenhouse counterpart. Bolletino del Grupo Micologico G. Bresadola, Nuova Serie 40: 457-464.
Vellinga, E.C. \& de Kok, R.P.J. 2002. Proposal to conserve the name Chlorophyllum Masse against Endoptychum Czer. (Agaricaceae). Taxon 51: 563-564.

Vellinga, E.C.; de Kok, R.P.J. \& Bruns, T.D. 2003. Phylogeny and taxonomy of Marolepiota (Agaricaceae). Mycologia 95: 442-456.

Vellinga, E.C. \& Yang, Z.-L. 2003. Volvolepiota and Macrolepiota - Macrolepiota velosa, a new species from China. Mycotaxon 85: 183-186.

Yang, Z.-L. 2000. Type studies on agarics described by N. Patouillard (and his co-authors) from Vietnam. Mycotaxon 75: 431-476. 